\title{
A mídia como artefato cultural e suas contribuições para a docência: diálogos sobre o uso do celular em sala de aula ${ }^{1}$
}

\author{
Luciane Cristina Silva ${ }^{2}$
}

Denise Rosana da Silva Moraes ${ }^{3}$

\section{Resumo}

Este texto ampliado propóe-se a discorrer sobre pesquisa de mestrado em andamento, vinculada ao Programa de Pós-Graduação Stricto Sensu Sociedade, Cultura e Fronteiras, vinculado à Universidade Estadual do Oeste do Paraná-UNIOESTE, em Foz do Iguaçu. Com a intenção de promover a formação continuada de professores/as, a pesquisa propôs a criação de um projeto de extensáo, grupo de estudos, sobre a temática mídia. Este projeto, intitulado A mídia como artefato cultural e suas contribuiçóes para a docência, nasce da investigação científica acerca desse tema e da observaçáo empírica no cotidiano escolar dos conflitos sobre o uso de instrumentos midiáticos como parte do seu acervo metodológico. Neste texto o objetivo é refletir sobre o uso do celular em sala de aula configurando as perspectivas dos/ as alunos/as e professores/as participantes e seus debates durante os encontros do grupo de estudos.

Palavras-chave: Formação de Professores/as; Celulares; Práticas Pedagógicas; Tecnologias.

\section{The media as a cultural artifact and its contributions to teaching: dialogues on cell phone use in the classroom}

\section{Abstract}

This expanded text proposes to discuss a master's research in progress, linked to the Stricto Sensu Post-Graduation Society, Culture and Borders, linked to the State University of the West of Paraná-UNIOESTE, in Foz do Iguaçu. With the aim of focusing on teacher

1 Este artigo, ampliado, foi apresentado no VII CONGRESSO INTERNACIONAL INTERDISCIPLINAR EM SOCIAIS E HUMANIDADES (CONINTER), de 12 a 16 de novembro de 2018 no Rio de Janeiro.

2 Aluna do programa de pós-graduação stricto-sensu em Sociedade, Cultura e Fronteiras - mestrado, na Universidade Estadual do Oeste do Paraná - UNIOESTE/Foz do Iguaçu. Pedagoga da rede estadual de Educação Básica do Paraná. E-mail: luciane_crisil@hotmail.com

3 Doutora em educação pela Universidade Estadual de Maringá (UEM), professora adjunta do Centro de Educação, Letras e Saúde (CELS), da Universidade Estadual do Oeste do Paraná - UNIOESTE/Foz do Iguaçu. Docente e Coordenadora do Programa de Pós-Graduação Strictu Sensu Interdisciplinar em Sociedade, Cultura e Fronteiras. E-mail: denisepedagoga@gmail.com. 
training, the research proposed the creation of an extension project, a group of studies, on the media theme. This project entitled "Media as a cultural artifact and its contributions to teaching" is born from scientific research on this subject and from the empirical observation in the daily school life of conflicts about the use of media instruments as part of its methodological heritage. In this text the objective is to reflect on the use of the cell phone in the classroom configuring the perspectives of the students and teachers and their debates during the group meetings.

Key-words: Teacher training; Cell Phones; Pedagogical Practices; Technologies.

\section{Introdução}

Diante da realidade em que se observa o ritmo acelerado de mudanças na educação, pensar na formação inicial do professor, ofertada nos cursos de graduação, como suficiente para todas as demandas que a escola apresenta, não é mais possível. $\mathrm{O}$ aprender mais sobre a sua profissão durante a prática educativa e o desenvolvimento profissional atrelado à formação continuada são requisitos cada vez mais exigidos do docente.

Com o avanço das Tecnologias de Informação e Comunicação (TICs), as mídias estâo presentes em todas as áreas da nossa vida. No caso da escola, elas se inserem como ferramentas de trabalho de grande valia e, ao mesmo tempo, a inovação tem se tornado um desafio para os docentes e cursos de licenciatura, quanto ao domínio e utilização em sala de aula. A este respeito, Moraes (2016) relata que a formaçáo para professores acerca dos usos sobre as mídias tem sido limitada à prática puramente instrucional, em vez de conhecer seu conceito, concepção e técnica. Ou seja, opta-se pela instrumentalização mecânica, desvinculando-as das possibilidades didático-pedagógicas.

Neste contexto, este artigo tem como objetivo apresentar as investigações iniciais e reflexóes das experiências vivenciadas nos primeiros encontros do grupo de estudos intitulado $A$ midia como artefato cultural e suas contribuiçóes para a docência, o qual se propôs a refletir sobre o uso das tecnologias no ambiente escolar, no que tange à apropriação da mídia pelos sujeitos da educação, especificamente, do uso do celular em sala de aula, configurando as perspectivas dos/as alunos/as e professores/as durante diálogos e debates no decorrer dos encontros. 
A problemática que incitou a pesquisa é a existência de tensões geradas pelo uso das tecnologias por parte dos/as alunos/as em sala de aula, especificamente, dos celulares/smartphones, ${ }^{4}$ e da aparente insegurança dos educadores e educadoras em mediar tais conflitos, bem como na utilização das tecnologias como recurso pedagógico. Consoante a essa situação, Moran (2013, p.12) reflete o seguinte:

Enquanto a sociedade muda e experimenta desafios mais complexos, a educação formal continua, de maneira geral, organizada de modo previsível, repetitivo, burocrático, pouco atraente. Apesar das teorias avançadas, predomina, na prática, uma visão conservadora, repetindo o que está consolidado, o que não oferece riscos nem grandes tensóes.

Assim sendo, o grupo de estudos e fonte desta pesquisa intenciona propiciar aos/às participantes momentos de reflexão sobre suas ações, sendo provocados a adaptarem a prática pedagógica às necessidades contemporâneas, aproveitando as tecnologias presentes na escola, como potenciais pedagógicos auxiliares na produção do conhecimento.

A pesquisa que embasa o projeto apresenta como aporte teórico os Estudos Culturais, uma vez que partem de experiências reais e contemporâneas. Nesses estudos, a interdisciplinaridade é construída ao conjugar saberes, proporcionando o encontro entre teoria e prática, entre objetivo e subjetivo, ao problematizar as mídias presentes no ambiente escolar, como artefato de cultura e como componente pedagógico contribuinte no processo de ensino e aprendizagem.

Sobre os Estudos Culturais, Giroux (2013, p. 94) explica que rejeitam o pressuposto de que os/as professores/as são simples transmissores de conhecimento existente. Em vez disso, defende que são intelectuais que produzem conhecimento e que "precisam desenvolver uma aprendizagem baseada no contexto e que leve em conta as experiências dos/as estudantes e suas relaçóes com a cultura popular e o terreno de prazer". Sobre isso o autor reitera:

Os Estudos Culturais exigem que os/as professores/as sejam educados/ as para serem produtores/as culturais, para tratar a cultura como

4 Neste texto a palavra celular e/ou smartphones refere-se aos aparelhos mais avançados que contam com tecnologias que vão muito além de ligaçōes e mensagens de texto. Geralmente são maiores em tamanho, com telas sensíveis ao toque, possuem acesso à internet e um sistema operacional complexo, como o Android, iOS ou Windows Phone. 
uma atividade inconclusa e aberta a contestação. Isso sugere que os/ as professores/as deveriam estar criticamente atentos/as às operaçóes do poder, na medida em que ele está implicado na produção de conhecimento e autoridade em suas salas de aula. Isso significa aprender a ser sensível a consideraçóes de poder, uma vez que ele está inscrito em todas as facetas do processo de escolarização. (GIROUX, 2013, p. 98).

Portanto, os Estudos Culturais oferecem oportunidades para os/as educadores/as repensarem suas práticas didáticas e problematizarem, no espaço escolar, as relaçóes entre cultura, conhecimento e poder, levantando questionamentos sobre a mídia como produtora de cultura e da escola como espaço de crítica e contestação da ideologia dominante.

Espera-se que os/as envolvidos/as, motivados pelas palestras, leituras e debates, concebam a mídia no ambiente escolar como um artefato de cultura, no qual o/a professor/a é autor/a de sua prática e que, desse modo, esses/as profissionais possam desconstruir a ideia de treinamento e repetição, com a qual estão "acostumados/as", pela própria formação pela qual passam, cuja importância é aparelhar escolas, em detrimento da formação de seus professores e professoras (MORAES, 2016). A previsão dessa formação específica contraria, como já explicitado, o treinamento. Por isso, a cada encontro os/as professores/as trocam experiências do uso das mídias em suas aulas e na escola como um todo. Já no último encontro, a ideia é de que apresentem e compartilhem, durante o seminário final, as açóes pedagógicas elaboradas e aplicadas por eles/elas em salas de aula e suas impressóes sobre o objeto estudado.

Para melhor organicidade, este texto está dividido didaticamente da seguinte forma: num primeiro momento apresentamos uma discussão teórica acerca da interdisciplinaridade como percurso metodológico, a seguir uma breve reflexão sobre as tecnologias digitais no ambiente escolar e a formação de professores/as no estado do Paraná. Finalmente, apresentamos reflexôes e diálogos vislumbrados durante os encontros do grupo de estudos sobre o uso do celular em sala de aula.

\section{A Interdisciplinaridade como Percurso Metodológico}

Os processos midiáticos têm modificado de forma visível nossa sociedade, produzindo diferentes formas de interação entre os indivíduos, mudanças comportamentais e culturais e, consequentemente, inovaçóes nos 
modelos de ensino e de aprendizagem. Sendo assim, propor uma pesquisa abordando as mídias como artefato cultural e suas contribuiçóes para a docência se faz urgente, uma vez que nosso século exige um novo formato de escola e um novo perfil de educadores/as que, diante de todas as inovaçóes tecnológicas e da intensificação dos fluxos de informaçôes, precisam se conscientizar da necessidade de agir e ensinar de maneira interdisciplinar.

Para a discussão teórica da temática, apresentam-se como pressupostos os Estudos Culturais, área de conhecimento em que os questionamentos envolvem a diversidade cultural e a comunicação, cujas bases estáo assentadas na interdisciplinaridade, que permite a compreensão das mídias e da tecnologia no ambiente escolar como componentes pedagógicos contribuintes ao processo de ensino e aprendizagem. Dessa forma, podemos dizer que a interdisciplinaridade vem para dinamizar, revolucionar e mudar práticas rotineiras e mecanizadas presentes no contexto pedagógico.

Para que a interdisciplinaridade aconteça com sucesso e as disciplinas "dialoguem", é necessário que existam representantes qualificados de cada uma delas, comprometidos com a colaboração interdisciplinar. Nesse sentido, Raynaut \& Zanoni afirmam que

a interdisciplinaridade ésempre um processo de diálogo entre as disciplinas firmemente estabelecidas em sua identidade teórica e metodológica, mas conscientes de seus limites e do caráter parcial do recorte da realidade sobre a qual operam. Isso implica, por parte dos pesquisadores, respeitar o saber produzido por outras disciplinas, recusando qualquer hierarquia a priori entre elas, relativas ao poder explicativo dos fatos sobre os quais trabalham. (RAYNAUT; ZANONI, 2011a, p. 103).

Alinhados à essa premissa, utilizamos a pesquisa-ação como caminho metodológico, que fortalece a escola como lugar de produção de saberes novos, cujos conhecimentos se cruzam e se combinam pelo diálogo entre as disciplinas, oportunizando a troca de experiências e a convergência de pontos de vista, bem como estratégias de aprendizagens.

Essa forma de pesquisa intervencionista interfere na realidade investigada, buscando modificá-la. E sendo realizada nos moldes da pesquisa-ação, que tem como uma das funçóes a transformação de uma realidade, é "instrumento de trabalho e de investigação com grupos, instituiçôes, coletividades de pequeno ou médio porte" (THIOLLENT, 2011, p. 15). 
Seguindo os moldes da pesquisa-ação, o grupo de estudos parte de um projeto de extensão e totaliza $40 \mathrm{~h}$, divididos em 10 encontros de $4 \mathrm{~h}$ (8 destes presenciais e 2 à distância) e prevê certificação aos/às participantes que atingirem no mínimo $75 \%$ de frequência. Cada encontro conta com estudo de textos, vídeos de apoio e debates, atividades que geram diálogos, reflexóes e troca de experiências que motivam a transformação na prática pedagógica. Ainda, em alguns encontros, está prevista a participação de convidados/as (professores/as e/ou pesquisadores/as da temática) que contribuem trazendo suas pesquisas, experiências e conhecimentos específicos relacionados ao projeto.

Com o intuito de refletir sobre a cultura da mídia no contexto escolar, como um problema concreto que demanda um "olhar" interdisciplinar, carente de contribuiçóes dialógicas das diferentes disciplinas curriculares, Japiassu (1994) defende que a tarefa interdisciplinar seja de cultivar o desejo de enriquecimentos por enfoques novos, combinando diferentes perspectivas e ultrapassando os caminhos já conhecidos e dos saberes já adquiridos pelas disciplinas curriculares.

Cabe frisar que, na pesquisa em mídias na educação, segundo a perspectiva interdisciplinar de Japiassu (1994), a escola se torna um lugar de produção coletiva de um saber novo, superando a distância ou, nas palavras do autor, "o corte universidade/sociedade, universidade/vida, saber/ realidade", instaurando uma nova relação entre educadores/as e alunos/as e permitindo a abertura de um novo nível de comunicaçáo, abandonando os velhos caminhos da racionalidade tradicional. O autor posiciona os/as educadores/as como agentes que despertam, que provocam, que questionam, e não que se "reduzam ao papel de disciplinadores intelectuais, revendedores de um saber-mercadoria". Nessa perspectiva, a pesquisa-ação contribui, pois é através dela que "é possível estudar dinamicamente os problemas, decisóes, açóes, negociaçóes, conflitos e tomadas de consciência que ocorrem entre os agentes durante o processo de transformação da situação" (THIOLLENT, 2011, p. 25).

Como já apontado, compreender as mídias e suas representações no ambiente escolar demanda o "cruzamento de olhares científicos distintos sobre uma mesma realidade empírica" e seu chamamento imperativo na atualidade, "pelo caráter híbrido dos problemas com os quais são confrontadas", implica uma tarefa interdisciplinar (RAYNAUT; ZANONI, 2011b, p.161). 
Nesse contexto, a escola que se constitui como um espaço de desenvolvimento de práticas coletivas é desafiada a conviver com as transformaçôes que as tecnologias e mídias digitais provocam na sociedade e na cultura e a pensarem estas como artefatos culturais que permeiam suas práticas cotidianas e como potenciais pedagógicos auxiliares na produçáo do conhecimento. Nesta perspectiva, Thiollent (2011) destaca as contribuiçóes da pesquisa orientada por esta metodologia:

os pesquisadores em educação estariam em condição de produzir informações e conhecimentos de uso mais efetivo, inclusive ao nível pedagógico. Tal orientaçáo contribuiria para o esclarecimento das microssituaçóes escolares e para a definição de objetivos de ação pedagógica e de transformaçóes mais abrangentes. A pesquisa-ação promove a participação dos usuários do sistema escolar na busca de soluçóes aos seus problemas. (THIOLLENT, 2011, p. 85).

Portanto, parte-se da proposta de ação-reflexão-ação, em um grupo de estudos, tendo a pesquisa-ação como suporte metodológico, a qual preconiza, além da participação do pesquisador, uma forma de ação planejada, de caráter social e educacional, que nem sempre se encontra em pospostas de pesquisa convencional. Thiollent $(2011$, p. 20) conceitua a pesquisa-ação como um tipo de pesquisa que propóe "a resolução de um problema coletivo no qual os pesquisadores e os participantes estão envolvidos e são representativos da situação ou do problema, atuam de modo cooperativo ou participativo".

\section{As tecnologias digitais na Educação e a formação de professo- res do estado do Paraná 5}

A chegada das tecnologias móveis à sala de aula traz tensões, novas possibilidades e grandes desafios. Segundo Moran (2013), o professor é mais importante do que nunca nesse processo de inclusão digital, pois ele precisa se aprimorar nessa tecnologia para introduzi-la na sala de aula, no seu dia a dia, da mesma forma que o professor que um dia introduziu o primeiro

5 Apresentamos apenas um recorte sobre como a formação de professores/as aconteceu no estado do Paraná nos últimos anos e com ênfase ao Portal Educacional. Sendo assim, podemos ter deixado de citar outras formas ou modelos de formação que aconteçam ou aconteceram no estado. 
livro em uma escola e teve que começar a lidar de modo diferente com o conhecimento - sem deixar as outras tecnologias de comunicaçáo de lado.

A formação docente para o uso das tecnologias digitais se fortalece ao se reconhecer que elas ressignificam a aprendizagem em função de uma nova visão de mundo e do ser humano, ao reconhecer que também alteram as práticas docentes e exigem destes/as que saibam incorporar e utilizar as novas tecnologias no processo de aprendizagem, exigindo uma nova configuração do processo didático e metodológico.

O uso das mídias em sala de aula precisa ser refletido pelo professor como algo além de um mero instrumento técnico, mas como algo de extrema importância pedagógica e que contribui com a qualidade educacional a partir de procedimentos didáticos que privilegiam a aquisição de conhecimentos. É preciso, parafraseando Moraes (2016), que haja domínio das técnicas e, principalmente, domínio pedagógico dos artefatos culturais no sentido de uma significaçáo, bem como de representação cultural para a vida na docência, o que subsidiará a prática docente crítica que tem sentido ao cumprir sua função, contribuindo para problematizar e formar para a liberdade e emancipação humana.

O estado do Paraná, através da Secretaria Estadual de Educação (SEED), oferece formaçóes e capacitação aos docentes da rede, como: Semana Pedagógica, Formação Continuada, Planejamento e Formação Disciplinar, de acordo com a Deliberação no 002/2002 do Conselho Estadual de Educação do Paraná (PARANÁ, 2002). As principais delas são definidas no calendário escolar, são presenciais e obrigatórias e ocorrem nas instituições de ensino, que devem seguir as orientaçóes e planejamentos fornecidos pela $\mathrm{SEED/PR}$. Os conteúdos, metodologias, horários e outros procedimentos são definidos e encaminhados pela SEED/PR e fiscalizados pelos representantes do NRE (Núcleo Regional de Educação).

O governo do estado dispóe de um site chamado Portal Educacional do Estado do Paraná (http://www.diaadia.pr.gov.br/), no qual estão disponibilizados, na aba de formação, os materiais e informaçóes necessárias sobre as formaçóes. Inclusive estão disponíveis neste portal todas as orientaçóes e materiais estudados desde 2015. Percebe-se que a autonomia da instituição escolar é limitada devido às inúmeras regras e imposiçóes feita pela mantenedora para a capacitação dos professores.

O NRE de Foz do Iguaçu, setor de Coordenação Regional de Tecnologia na Educação (CRTE), também oferta cursos de "Google drive”, por 
exemplo, aos/às professores/as e funcionários/as, para introdução ao software e seus recursos, no qual os participantes são orientados a utilizá-los como ferramenta metodológica.

Moraes (2016) reforça a necessidade da formação do professor para o uso das mídias, dialogando com as dimensóes teóricas e práticas de forma contextualizada, conforme descrito a seguir:

A formação para a utilização das mídias, bem como o acesso aos seus aparatos, consiste em uma operação que dá internamente e não institucionalmente apenas. É uma assunção de cada um, que exige o exercício da dúvida, da vigilância epistemológica, desejo e desafio para desaprender o que já não responde mais à prática e disposição para novas aprendizagens. Uma formação que contribui para a produção, como consequência de uma natural transversalidade dos conteúdos que estão e precisam estar perfeitamente contextualizada com a vida cotidiana e com uma prática redimensionada política e pedagogicamente. (MORAES, 2016, p. 24-25).

Para tanto, faz-se necessário refletir e buscar novos caminhos que nos conduzam a novas perspectivas em relação à formação de professores, repensando o passado e projetando um futuro com base no conhecimento pedagógico. Segundo Moraes (2016, p.19), "na formação de professores/as, é possível conhecer e analisar as possibilidades de intervenção pedagógica utilizando o potencial pedagógico das redes sociais digitais e viabilizar uma prática de ensino que favoreça a compreensão do conteúdo escolar”.

Mesmo com todas as orientaçôes e proposiçóes das formaçóes presentes na documentação escolar e nas diretrizes curriculares que contemplam o uso das tecnologias digitais como recurso metodológico, de certa forma, a maneira como cada escola lida com esse novo cenário depende da perspectiva que seus profissionais têm do uso de tais dispositivos em sala de aula. Acerca dessa realidade, Fantin reflete que

parece que hoje um dos grandes desafios da escola e da formação diz respeito à finalidade da educação no sentido de enriquecer a vida de crianças e jovens com repertórios e recursos cognitivos, sociais, éticos, estéticos e culturais em consonância com os desafios de uma sociedade em constante transformação, profundamente marcada pela tecnologia. (FANTIN, 2012, p. 57). 
Nesse sentido, Nóvoa (1995, p. 26) orienta que "a formação de professores precisa ser repensada e reestruturada como um todo, abrangendo as dimensões da formação inicial, da indução e da formação contínua”. Faz-se necessário pensar a formação de professores/as de uma maneira contínua, que abranja desde a formação inicial até a formação continuada, independentemente de seu tempo de atuação como professor/a, pois o exercício cotidiano da docência exige constante atualização e acesso a conhecimentos que venham a contribuir e a somar à sua prática pedagógica, seja inicial ou continuada.

Face ao exposto, destaca-se a importância em organizar um projeto de formaçáo docente que permita a reflexão sobre o uso das tecnologias no ambiente escolar para que, conforme Moraes (2016, p. 28), "a tecnologia passe a ser entendida como fortalecedora das práticas pedagógicas se tiver como objetivo uma aproximaçáo com a arte, ocorrendo o contrário, quando reduzida a uma questão puramente instrumental”.

\section{Reflexóes e diálogos iniciais no Grupo de Estudos: o uso do celular em sala de aula}

Durante a semana pedagógica de julho/2018, no Colégio Estadual Tancredo de Almeida Neves, em Foz do Iguaçu - Paraná, realizamos a divulgação e o convite para o grupo de estudos, a realizar-se na escola. Nesse dia, apresentamos a temática, bem como a proposta do grupo aos/às professores/ as presentes que demonstraram interesse. Também houve questionamentos sobre a possibilidade de participação de professores/as da rede municipal e de funcionários da escola, e a sugestão foi aceita, pois a contribuição de profissionais de outras instituiçóes e redes de ensino seria relevante e substancial para os diálogos e troca de experiências.

Constatou-se, após o recebimento de 30 fichas de inscrição dos interessados, um perfil diversificado de professores/as de variadas disciplinas e funcionários/as da escola e, no dia seguinte, o convite estendeu-se para os/as alunos/as do mesmo colégio, com retorno de 5 estudantes interessados em participar. Para melhor interagir e organizar os encontros do grupo, criaram-se canais de comunicação: um grupo de conversa, no whatsapp e um email coletivo na plataforma do gmail.com para postar e compartilhar o material do curso através do drive. 
O primeiro encontro aconteceu no dia 11/08/2018, uma manhã de sábado, e compareceram 24 participantes que, após a apresentação do curso pela coordenadora do projeto, também se apresentaram e relataram suas funçóes na escola e suas experiências com as mídias e as tecnologias digitais no dia-a-dia. Foram observados variados pontos de vista e opinióes sobre a temática: professores/as que se sentem desatualizados por não terem muita proximidade com as tecnologias, usando-as apenas em extrema necessidade; relatos de professores/as que se sentem desconfortáveis em casa, pois os filhos não dispensam o smartphone nem durante as refeiçóes; o relato de uma funcionária da escola que se posicionou contrária ao uso e introdução das tecnologias no ambiente escolar, inclusive disse náo usar e preferir o mais simples aparelho de celular. Outra participante afirmou que a temática proposta pelo curso despertou sua curiosidade e necessidade em aprender mais e saber como pode melhorar sua prática utilizando tais recursos com orientação e conhecimento. Na mesma perspectiva, uma participante, coordenadora pedagógica do colégio, falou sobre precisar aprender para poder auxiliar alunos/as e professores/as a lidar com essa nova cultura que adentra nossas vidas. Corroborando, Fantin afirma que

a cultura digital é uma cultura em que a mídia pessoal, personal media, é a protagonista. Os celulares e as redes sociais, social network, ao lado de outras tecnologias, permitem que o leitor se torne cada vez mais autônomo, e graças a essa cultura, cada leitor pode se tornar também um autor. É nessa cultura que crianças, jovens e alunos da escola mergulham, pois esse é o seu meio ambiente. (FANTIN, 2012, p. 98).

Na sequência, outra professora, esta da disciplina de Filosofia, aponta a dualidade que a mídia nos apresenta: ser "atrativa e perigosa" ao mesmo tempo. Ela diz se sentir insegura ao pesquisar e procurar material para suas aulas e sobre a forma como os estudantes utilizam a internet, e que tais problemáticas precisam ser refletidas e debatidas na escola. Moran (2013) faz um alerta quanto a esta dualidade relacionada ao ambiente escolar.

Diante de tantas possibilidades de busca, a própria navegação torna-se mais sedutora do que o necessário trabalho de interpretação. É mais atraente navegar, descobrir coisas novas, do que analisá-las, compará-las, separando o que é essencial do acidental, hierarquizando ideias, assinalando coincidências e divergências. (MORAN, 2013, p. 57). 
Também nesse primeiro encontro, observou-se, pela participação do grupo e dos comentários sobre suas expectativas e experiências, que a temática desperta interesse e a proposta metodológica da pesquisa-ação sugere um ambiente de produçáo coletiva, de troca de conhecimentos que valoriza o diálogo, a cooperação e a crítica. $\mathrm{O}$ debate inicial foi sobre o tempo da escola e as aprendizagens prévias dos/as alunos/as, e sobre como os/ as professores/as lidam com as situaçóes em torno das tecnologias digitais, principalmente a internet e as redes sociais. Os estudos e debates fluíram de forma muito favoráveis porque, além de educadores, participam alunos/ as, que comentam e compartilham suas impressóes sobre a temática e suas experiências escolares.

O segundo encontro aconteceu no dia 25/08/2018 e se iniciou com o vídeo: A importância da Tecnologia na Educação, abordando a evolução das tecnologias e destacando sua utilização no ambiente escolar como suporte pedagógico. Como embasamento teórico estudou-se o texto Internet: novos valores e novos comportamentos, do livro: A leitura nos Oceanos da Internet, obra citada no referencial deste artigo, que introduziu a discussão sobre a cultura digital gerada pelo uso das tecnologias, principalmente pelas crianças, e as relaçóes estabelecidas através do contato com a internet. "As crianças têm utilizado a Internet para brincar, para aprender e principalmente para se comunicar e formar relacionamentos, incluindo, nesse processo interativo, o desenvolvimento diferenciado de sua cognição, inteligência, raciocínio, criatividade e personalidade" (SILVA, 2008 p. 46).

Para Silva (2008), a internet possibilita ao jovem novas formas de perceber a realidade social ao se conectar e receber informaçóes, ampliando suas potencialidades de aprendizado e "é fundamental reconhecer que o computador se tornou um novo ambiente cognitivo". O mesmo autor explica que o contato e/ou utilização da internet pelos jovens oportuniza o desenvolvimento de habilidades de "investigação e seleção do que lhes é oferecido, tais como orientação espacial, coordenação motora-visual e a percepção sensorial". Ainda sobre as complexidades do processo de aquisição do conhecimento através do uso da internet, o pesquisador afirma o seguinte:

é preciso reiterar que ela tem como uma de suas características a possibilidade de diminuir as diferenças historicamente estabelecidas entre diversão e educação. A interatividade do meio virtual leva ao questionamento de posturas metodológicas tradicionais frequentemente mascaradas pelo uso de tecnologias em sala de aula. (SILVA, 2008, p. 48). 
Durante o debate um dos participantes destacou a falta de preparo dos jovens em utilizar a internet para estudar ou aprender, disse ainda que os/as alunos/as se distraem com facilidade durante as explicaçóes dos conteúdos das aulas e que, devido ao grande número de informaçóes e recursos disponíveis na rede, facilmente aconteceria o mesmo utilizando o celular na sala de aula. Outro/aprofessor/a do grupo faz uma crítica ao texto debatido, afirmando que os/as alunos/as gostam de utilizar as tecnologias digitais, principalmente o smartphone, para seu entretenimento (jogos, músicas, redes sociais etc.), e que a utilização durante as aulas, constantemente, gera desconforto e conflito, pois precisa chamar a atenção e até mesmo solicitar a entrega do aparelho.

Com estes relatos, é possível perceber que há muitas dúvidas entre os/as professores/as sobre a melhor forma de lidar com as novas tecnologias dentro da sala de aula, principalmente o celular. Alguns/umas adotam como método a proibição pura e simples dos celulares em sala de aula, por exemplo, enquanto outros/as argumentam que é melhor aproveitar essas tecnologias para estimular o aprendizado dos alunos. Nesse sentido, Moran (2013, p. 31) defende que, ao aceitar as tecnologias como ferramenta metodológica de produção de conhecimento, "a escola pode transformar-se em um conjunto de espaços ricos de aprendizagem significativa, presenciais e digitais, que motivem os alunos a aprender, a pesquisar o tempo todo, a serem proativos, a saber tomar iniciativa e interagir", enfim, a fazerem parte do processo de ensino.

Ao tratar da formação de professores/as e mídia-educação, Fantin (2012, p. 64) enfatiza a necessidade da criação e do desenvolvimento da competência midiática "que envolva a apreciação, a recepção e a produção responsável", auxiliares na construção de atitudes críticas "em relação aos modos de ver, navegar, produzir e interagir com as mídias e as tecnologias". A autora destaca que a formação deve dialogar com a realidade da escola e que a cultura digital está produzindo novas formas de interação que precisam ser problematizadas nos currículos de formação de professores.

Em princípio, percebe-se que para fazer parte da vida escolar, as tecnologias digitais, neste caso, os celulares/smartphones, precisam ser utilizados de forma correta, e a formação e atualização dos/das docentes é necessária para que tais tecnologias não sejam vistas apenas como um acessório ou aparato marginal. Nesse sentido, Brito e Purificação afirmam que 
tornam-se primordiais a formação e transformação do professor, que deve estar aberto às mudanças, aos novos paradigmas, os quais o obrigarão a aceitar as diversidades, as exigências impostas por uma sociedade que se comunica através de um universo cultural cada vez mais amplo e tecnológico.(BRITO; PURIFICAÇÃO, 2008, p. 29).

No terceiro encontro do grupo de estudos, ocorrido no dia 01/09/2018, o assunto da utilizaçáo do celular em sala de aula foi retomado, devido a um fato relatado pela professora de Filosofia. Segundo a participante, uma das turmas em que leciona criou um grupo no aplicativo de conversas whatsapp e adicionou os professores da turma; mas o que causou sua "surpresa" foi que estavam utilizando a ferramenta apenas para conversas relativas à escola, às disciplinas e ainda para comunicar suas faltas quando fosse preciso. Durante esta conversa, surgiram comentários positivos em relação ao uso do celular.

Sobre os/as professores/as assumirem o uso das mídias móveis como ferramenta pedagógica, Machado (2012, p. 2) cita algumas possibilidades de trabalho com o celular em sala de aula,como "criação de banco de imagens, gravação de vídeos e documentários, envio de mensagens sobre dúvidas e avaliaçóes, utilização de agendas e aplicativos para organização da vida escolar, entre outras".

Outra participante, esta professora de Educação Física, comentou que após as reflexôes desencadeadas no encontro passado, ela resolveu experimentar a "novidade" e solicitou que os/as alunos/as do $9^{\circ}$ ano do Ensino Fundamental utilizassem o aparelho de celular em busca de vídeos para uma pesquisa sobre o conteúdo da aula: a capoeira. Muitos sentaram com um colega porque náo tinham acesso à internet no seu aparelho para realizar a atividade. A docente finalizou dizendo que a aula foi muito produtiva, pois os alunos estavam motivados, participaram e demonstram interesse pelo conteúdo.

Segundo este escopo, Brito e Purificação destacam que

a internet veio para mexer com os paradigmas educacionais, em que não cabem mais arbitrariedade de opinióes, linearidade de pensamento, um único caminho a ser trilhado. Recorrer a uma nova forma de integrar a internet no processo de comunicaçáo com nosso aluno, buscando a formação de um sujeito para um mundo em transformação, no mínimo é possibilitar a visão de uma realidade em que as informaçôes chegam sob diferentes óticas, e cabe ao professor a análise junto com seu aluno de um descortinar de "verdades". (BRITO; PURIFICAÇĀO, 2008, p. 108). 
Durante os debates sobre o uso do celular, um dos alunos participantes relatou sobre como utiliza a internet e o aparelho celular: para estudar, fazer pesquisas em sites de buscas, preferindo textos de sites de conteúdos educativos que são mais confiáveis; para interagir e se comunicar, através das redes sociais e aplicativos de conversa; e para divertimento, jogando ou ouvindo músicas. Nas palavras de Castells (2003), a internet tem um efeito positivo sobre a interação social e tende a aumentar a exposição a outras fontes de informação.

Outro estudante comentou sobre os atritos que presencia na sua sala de aula quando o/a professor/a proíbe o uso dos aparelhos celulares, quando os encaminha para a coordenaçáo pedagógica para serem advertidos por utilizarem fones de ouvidos e, principalmente, quando querem fotografar o conteúdo do quadro e sáo coibidos. Tais relatos evidenciam que os jovens chegam à escola contando com inúmeras fontes de informaçấo e variados ambientes para aprender, visto que a internet ampliou as possibilidades de comunicaçấo entre os usuários que estáo conectados nos mais diversos lugares do planeta e possibilita o surgimento de novas formas de transferência de informaçōes e de compartilhamento.

Apenas para evidenciar o crescente acesso à internet e à utilização do celular, vale destacar que no $4^{\circ}$ trimestre de 2017, o IBGE divulgou uma pesquisa sobre o Acesso à Internet è à televisáo e posse de telefone móvel celular para uso pessoal, pesquisa do tipo PNAD Contínua (Pesquisa Nacional por Amostra de Domicílios). Segundo a pesquisa, 63.6\% dos lares brasileiros têm acesso à internet, sendo que a grande maioria usa o smartphone para se conectar $(60.3 \%)$. Já $40.1 \%$ utilizam o computador, sendo que outros $12.1 \%$ usam tablets, $7.7 \%$ a TV e $0.8 \%$ outro equipamento, conforme o gráfico abaixo: 


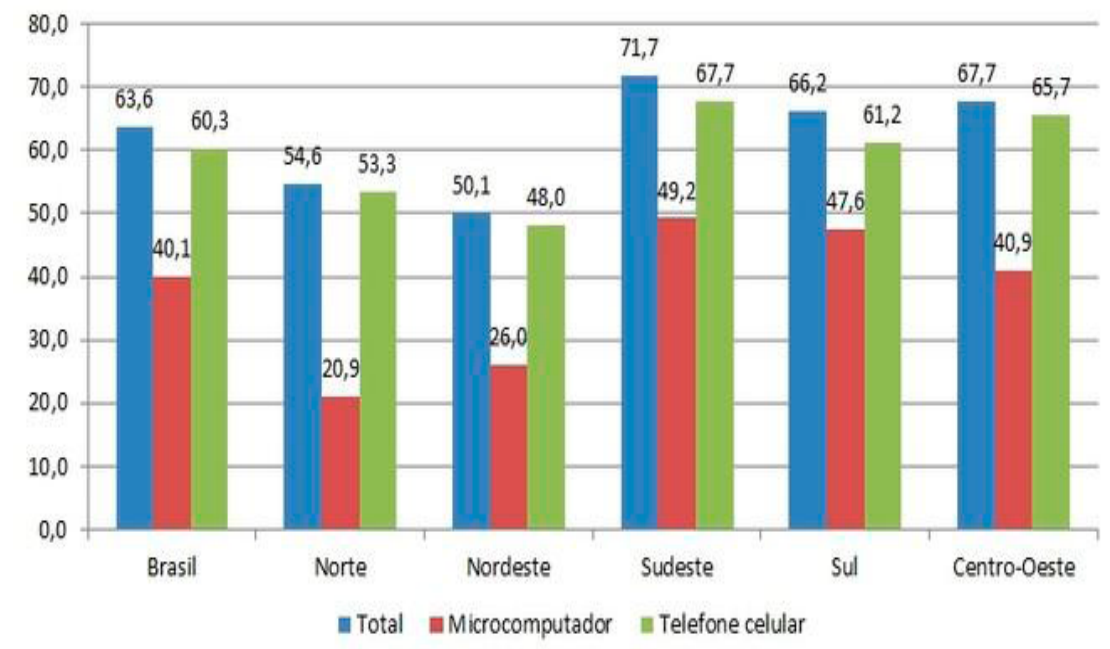

Fonte: http://t.tudocdn.net/303581?w=1000\&fit=clip

A pesquisa também revelou que a região sudeste concentra o maior percentual de domicílios com acesso à internet (71.7\%), enquanto a região norte registrou o menor percentual de domicílios com acesso via computador $(20.9 \%)$. Já a região nordeste tem o menor percentual de acesso à internet via smartphones (48.1\%).

Como evidenciado nos relatos e confirmado pela pesquisa do IBGE, as tecnologias estão cada vez mais próximas do/a professor/a e do/a aluno/a e precisam ser exploradas pela escola. Isso significa que utilizando o celular, mediados/as pelo/a professor/a, os/as alunos/as constroem caminhos para o aprendizado, buscando conhecimento e atuando como participantes do processo de aprendizagem. Além disso, a internet concede acesso a mídias sofisticadas que permitem interatividade com programas, interação com outros internautas e acesso à informação e entretenimento, tudo na palma da mão e sem limites de tempo e espaço. Segundo Moran (2013), a internet é uma mídia que facilita a motivação dos alunos, pela novidade e pelas possibilidades inesgotáveis de pesquisa que oferecem.

Nesse sentido, é possível perceber que a participação dos/as alunos/as foi fundamental e bem recebida pelos/as docentes, uma vez que é para eles/ as, segundo os/as participantes, que se busca melhorar a prática e ouvi-los/as é a melhor forma de entendê-los/as. Moran (2013, p.13) aponta para a parti- 
cipação ativa dos alunos: "se os alunos fizerem pontes entre o que aprendem intelectualmente e as situaçóes reais, experimentais e profissionais ligadas aos estudos, a aprendizagem será mais significativa, viva e enriquecedora”.

Os debates destes primeiros encontros sobre o uso do celular em sala de aula resultaram em reflexóes sobre como as tecnologias digitais podem se constituir, pela vivência, em um aparato pedagógico e/ou material de apoio que potencializa o processo de ensino e aprendizagem em sala de aula, com repercussão nos espaços escolares e minimizando os conflitos.

Os depoimentos apresentados indicam que os/as participantes se tornaram mais reflexivos em relaçâo à própria prática pedagógica e também mais flexíveis em relação ao uso do celular/smartphone em sala de aula.

Grande parte das leituras propostas nos encontros do grupo são produções críticas e contextualizadas de autores como Castells (2003), Brito e Purificação (2008), Moran (2013), Fantin (2012), Moraes (2016), entre outros, fundamentais ao debate de como a tecnologia pode ser mais que uma mera ferramenta, mas um artefato de cultura, que auxilia na prática pedagógica e na produção do conhecimento, aproximando diferentes saberes de alunos/as e professores/as para além do conflito, na direção da construção de práticas coletivas e solidárias.

Percebe-se, e as leituras teóricas auxiliam nessa percepção, que os processos midiáticos têm modificado de forma visível nossa sociedade, produzindo diferentes formas de interação entre os indivíduos, mudanças comportamentais e culturais e, consequentemente, inovaçóes nos modelos de ensino e de aprendizagem.

A escola, assim como outros contextos do mundo contemporâneo, sente os reflexos da cultura digital e estudar a mídia e as tecnologias digitais, presentes neste contexto, com os sujeitos que as experimentam, é fundamental para pensar práticas de análises e, principalmente, repensar novos paradigmas, permitindo às pessoas outro tipo de posicionamento, de referenciais necessários para a compreensão da realidade e da possibilidade de intervenção através da prática pedagógica.

Espera-se que no decorrer do curso, os diálogos e reflexóes propostos possam instigar novas trilhas e construçóes pedagógicas que nos aproximem de uma vida cultural mais rica e significativa na formação dos/as estudantes. 


\section{Consideraçóes Finais}

O estudo apresentado aqui, nos limites de um artigo científico, teve como objetivo demonstrar o caminho e a tessitura da pesquisa de mestrado, cujo fenômeno é a investigação da ação pedagógica de professores e professoras com o uso das mídias. Para isto, organizamos um projeto de extensão, inédito, pois os/as participantes foram professores/as, alunos/as e funcionários/as da escola. Essa interlocução rendeu frutos e debates acerca do cotidiano da escola e das práticas em relação às mídias.

Nos primeiros encontros já realizados observou-se, pela participação do grupo e dos comentários sobre suas expectativas e experiências, que a temática desperta interesse e a proposta metodológica da pesquisa-ação sugere um ambiente de produção coletiva, de troca de conhecimentos que valoriza o diálogo e a crítica.

A intervenção foi possível pela proximidade com os sujeitos da pesquisa, uma vez que já havia a atuação da pesquisadora como formadora de professores naquele contexto, através do órgão estadual que coordena aquelas instituiçôes escolares, dentre outras. Como já afirmamos, após a exploração do material já coletado com a aplicação dos questionários em outras formaçóes, sentimos a necessidade de nos colocar como elemento de intervenção, buscando a reflexão docente e a sua apropriação quanto às habilidades para uso dos dispositivos digitais, neste caso, o celular, que podem servir aos propósitos pedagógicos no contexto de sala de aula. Durante essa fase, foi feita a coleta de falas e relatos dos/as docentes nas plataformas digitais que utilizamos durante a formação.

Assim, buscamos encontrar nos relatos e falas dos sujeitos a compreensão sobre quais fatores contribuem para a utilização dos dispositivos digitais em ferramentas pedagógicas integradas ao cotidiano das salas de aula, vindo a contribuir para experiências exitosas nesses contextos. Embora compreendamos que nem sempre os escritos serão fidedignos aos acontecimentos em sala de aula, pensamos que as interpretaçóes que fazem dessas experiências trazem muito dos sentimentos e sentidos que o/a próprio/a docente incorpora às suas açóes e, justamente por isso, implicam nos resultados obtidos junto ao corpo discente.

Dessa maneira, é importante que a formação de professores incorpore discussóes sobre o uso dessas tecnologias no contexto educacional, tendo em vista a preparação de profissionais mais conscientes. $\mathrm{O}$ uso do celular é, 
em particular, uma questão que ainda apresenta dificuldades diversas, que devem ser discutidas. A proibição do uso desses dispositivos em sala de aula pode nem mesmo impedir a ocorrência de problemas, pois os alunos driblam, muitas vezes, as restriçóes. Trata-se de uma questão ampla, que requer bom senso e diálogo, mesmo que seja apenas para justificar os motivos da proibição.

Considera-se o artigo relevante para os sujeitos envolvidos no processo educativo, tendo em vista que situa a tecnologia digital como importante instrumento pedagógico, interpretando seus usos, suas formas de produção e transformação da cultura. Enfim, analisa como aproveitar smartphones e outros dispositivos tecnológicos, presentes na escola, para favorecer o envolvimento dos/as estudantes e contribuir para a promoção do conhecimento, bem como aproximar o diálogo entre alunos/as e professores/as em um ambiente digital e real de alteridade.

\section{Referências}

BRASIL. Lei n. ${ }^{\circ}$ 9.394, de 20 de dezembro de 1996. Estabelece as diretrizes e bases da educação nacional. Diário Oficial [da] República Federativa do Brasil, Brasilia, DF, 23 dez. 1996. Disponível em: http://www.planalto.gov. br/ccivil_03/leis/L9394.htm. Acesso em: 06/09/2018.

BRITO, Gláucia da Silva; PURIFICAÇÃO, Ivonélia da. Educação e novas tecnologias: um (re)pensar. 2. ed. Curitiba: IBPEX, 2008.

CASTELLS, Manuel. A Galáxia Internet: reflexóes sobre a Internet, negócios e a sociedade. Zahar, 2003.

FANTIN, Monica; RIVOLTELLA, Pier Cesare (org.). Cultura digital e escola: pesquisa e formação de professores. Papirus, 2012.

GIROUX, Henry A. Praticando Estudos Culturais nas Faculdades de Educação. In: SILVA, Tomaz Tadeu (org.). Alienígenas na sala de aula:uma introdução aos estudos culturais em educação. Petrópolis, RJ: Vozes, 11. ed. 2013.

JAPIASSU, Hilton. A questão da interdisciplinaridade. Seminário internacional sobre reestruturação curricular. Secretaria Municipal de Educação, Porto Alegre, 1994. 
MACHADO, João L. de Almeida. Celular na Escola: O que fazer? 2012. Disponível em: http://cmais.com.br/educacao/celular-na-escola-o-quefazer. Acessado em: 05/03/2019.

MORAES, Denise Rosana da Silva. Midias na Formação de Professores(as): limites e possibilidades. Jundiaí: Paco Editorial, 2016.

MORAN, José Manuel. Novas tecnologias e mediação pedagógica. São Paulo: Papirus Editora, 2013.

NÓVOA, António. Profissão professor. 2.ed. Porto: Porto, 1995.

RAYNAUT, Claude. Interdisciplinaridade: mundo contemporâneo, complexidade e desafios à produção e à aplicação de conhecimentos. In: PHILLIPI JR. Arlindo; SILVA NETO, Antônio J. Interdisciplinaridade em ciência, tecnologia e inovação. Barueri, SP: Manole, 2011a. p. 69-105.

RAYNAUT, Claude; ZANONI, Magda. Reflexôes sobre princípios de uma prática interdisciplinar na pesquisa e no ensino superior. In: PHILLIPI JR. Arlindo; SILVA NETO, Antônio J. Interdisciplinaridade em ciência, tecnologia e inovação. Barueri, SP: Manole, 2011b. p. 143-208.

SILVA, Ezequiel Theodoro da (coord.) A leitura nos oceanos da internet. 2. ed. São Paulo: Cortez, 2008.

SILVA, Tomaz Tadeu da (org.). Alienígenas na sala de aula: uma introdução aos estudos culturais em educação. Petrópolis, RJ: Vozes, 2013.

Portal Educacional do Estado do Paraná. Disponível em: http://www.diaadia. pr.gov.br/. Acesso em: 11 set. 2018.

Video: A importância das tecnologias na educação. Disponível em: https:// www.youtube.com/watch?v=VV3TdtDm7so . Acesso em: 05 jul. 2018.

IBGE. Pesquisa do tipo PNAD - Acesso à Internet e à televisão e posse de telefone móvel celular para uso pessoal. Disponível em: https:// www.ibge.gov.br/estatisticas/sociais/trabalho/17270-pnad-continua. html?edicao=23205\&t=sobre. Acesso em: 07 mar. 2019.

Recebido em: 22 jun. 2019.

Aceito em: 12 nov. 2019. 